\title{
THE ANALYSIS OF BUYING AND SELLING OF GOODS WITHOUT PRICE TAGS IN THE PERSPECTIVE OF FIQH MU'AMALAH AT STUDENT COOPERATIVE STORES OF PMDG CAMPUS
}

\author{
Haerul Akmal; Teguh Eka Prasetya; Abdurrahman Azmi \\ Universitas Darussalam Gontor Ponorogo \\ e-mail: haerulakmal@unida.gontor.ac.id; teguhekaprasetya@unida.gontor.ac.id; \\ abdurrahmanazmi@gmail.com
}

\begin{abstract}
This research aims at finding out the practice of selling goods without price tags and the fiqh mu'amalah review on its sales at student cooperative stores of PMDG Campus. The method used in this research is descriptive qualitative which describes the various conditions, situations and social phenomena that occur. Applying the field research, this study uses the interview results with the management of student and consumer cooperatives, as a source of data collection. Based on this research, sales in student cooperatives apply the same system as in supermarkets, where the consumer takes the items he wants to buy on the storefront, then takes them to the cashier to carry out the transaction process. Since the price tag is not included, the price given by the cashier sometimes changed or unclear. Hence, it can be assumed that the sale of goods without the use of price tags in student cooperatives Store still has a light gharar element, which lies in pricing. Due to the absence of a price tag, the management of the student cooperative sometimes speculated on their merchandise, giving rise to gharar. However, the gharar that occurs does not happen at the core of the trade, and does not cause hostility, so the buying and selling practice in student cooperatives store is legal.
\end{abstract}

Keywords: buying and selling; price tags; fiqh mu'amalah

\section{Introduction}

One form of mu'amalah in Islam is buying and selling, which is an agreement in which one party binds himself to hand over an object and the other party pays a price that has been agreed by both. ${ }^{1}$ In other words, buying and selling is an activity of exchanging goods for goods, or property for assets, which is carried out by buyers and sellers with sighah, namely the statement of offer ( $\overline{i j} a b)$ and acceptance (qabul), carried out voluntarily between each party, and these assets exchanged are those that are of beneficial value. ${ }^{2}$

In terms of buying and selling, Islam has also stipulated its legal rules as taught by the Prophet SAW, both regarding the pillars, terms, as well as trading which is allowed or not allowed. A sale and purchase transaction is a legal action that has a consequence of the transfer of rights to an item from the seller to the buyer, then naturally in a legal act the term (essential part) and conditions must be fulfilled. ${ }^{3}$

\footnotetext{
1 Pusat Pengkajian Hukum Islam dan Masyarakat Madani, Kompilasi Hukum Ekonomi Syariah (Jakarta: Kencana, 2009), 16.

${ }^{2}$ Dimyaudin Djuwaini, Pengantar Fiqh Muamalah (Yogyakarta: Pustaka Pelajar, 2008), 69.

${ }^{3}$ Mardani, Fiqih Ekonomi Syariah: Fiqih Muamalah (Jakarta: Kencana, 2012), 2.
} 
In buying and selling, there are several terms (essential part) and conditions that must be fulfilled by the parties, so that the sale and purchase is said to be valid by the sharia. There are four pillars in buying and selling, namely the existence of people who have contract, the existence of sighah ( $\overline{i j} a b$ and $q a b u l)^{4}$, there are goods purchased, there is a replacement exchange rate for these goods. Meanwhile, there are four conditions for a sale and purchase, the conditions for the contracted person, the conditions related to the consent granted, the terms for the goods to be bought and sold, and the terms for the exchange rate of the goods (the price of the goods) such as halal labelling on food product. ${ }^{5}$ Regarding the conditions for the exchange rate of an item (price of goods), what must be fulfilled is knowing the price of the goods being sold with a nominal number. ${ }^{6}$

Islam prohibits all forms of transactions that contain elements of crime, fraud, tyranny and exploitation. Where the rights of all parties involved in an economic behavior are not clearly explained (openly/clearly), it will result in some of the parties involved taking advantage, but at the expense of the other party. ${ }^{7}$ One of the practices that are prohibited in Islam, but commonly carried out in business is non-transparent buying and selling, which causes each transaction to give an opportunity for a dispute, because the goods being sold are not transparent, or there is an element of gharär or fraud that can generate enmity between two parties, who transact. ${ }^{8}$

In trading activities, detrimental to the rights of others is an act of wrong doing which can cause bad feelings in the soul of the wronged person such as feelings of revenge, jealousy and even despair from justice and goodness, which are all feelings that can destroy the atmosphere of life and social relations, so that there is no godliness in life and can cause enmity. ${ }^{9}$

At Modern Islamic Boarding School Darussalam Gontor, Campus 5, Magelang, there are several Boarding School business units, one of which is the Student Cooperative stores which sells various types of basic and daily needs needed by students, apart from meeting the needs of students, shopping at student co-operatives stores is also relatively practical, so that it becomes the preferred place for students to shop. Darul Qiyam Student Cooperative has been established since 2001, exactly two years after the inauguration of the Darussalam Gontor campus 5 Modern Islamic Boarding School in 1999. The student cooperative itself has several mottos that are firmly adhered in every transaction, one of which is, "Neat administration, an absolute obligation for maintain trust" and "You shop, you do charity".

Buying and selling transactions that are currently commonly practiced in Student Cooperatives stores are that the seller offers his merchandise by displaying the goods on

\footnotetext{
${ }^{4}$ Parmujianto, "Analisis Fikih Mu'amalah Kontemporer terhadap Jual Beli Online dengan Sistem Transaksi Drpoship (Kajian Hukum Islam)", Al Qodiri: Jurnal Pendidikan Sosial dan Keagamaan, Volume 16, Number 1 (April 2019), 85.

${ }^{5}$ Iyut Riszki Utami, "Halal Food Product Labelling According to Islamic Business Ethics and Consumers Protection Law", Jurnal al Iktisab, Volume 2, Number 2 (2018), 1.

${ }^{6}$ Hadi Mulyo dan Shobahussurur, Falsafah dan Hikmah Hukum Islam (Semarang: CV. Adhi Grafika, 1992), 375.

${ }^{7}$ Yusuf al-Qardlawi, Halal Haram dalam Islam (Solo: Era Intermedia, 2000), 204.

${ }^{8}$ Sulaiman Rasyid, Fiqh Islam (Bandung: Sinar Baru Algensindo, 2005), 286.

${ }_{9}^{9}$ Aulia Muthiah, "Perlindungan Konsumen terhadap Produk Cacat dalam Perspektif Fiqih Jual Beli", Syariah: Jurnal Hukum dan Pemikiran, Volume 18, Number 2 (December 2018), 211-232.
} 
special shelves that have been arranged in such a way as to the type of goods needed by consumers, this is done to make it easier for consumers to find it. After the consumer finds the product or item he needs, the consumer brings the item to the cashier and pays for it without any consent process.

In the buying and selling process itself, problems often occur between buyers and sellers, which can ruin the convenience in the buying and selling process, and also cause losses, both for seller and buyer. For example, buying and selling transactions found at the Student Cooperative stores PMDG Campus 5, Magelang. Some buyers feel that their rights as consumers are not fulfilled, so they feel disadvantaged. For example, the management of student cooperatives does not put a price tag on their merchandise, even though the price tag is very important, because with the price tag, consumers are greatly helped when choosing products and shopping at student co-operatives stores.

Even in some cases, when a consumer buys an item in a student co-operative stores, sometimes the student cooperative manager determines the price of the item by only estimating it, because he does not know the price, then there is a difference between the original price of the item and the price given by the cashier to the buyer. So that the sale and purchase transaction causes speculation or gharar, which is prohibited by Islam.

\section{Research Methodology}

Based on the problems to be studied, these problems will be studied with a qualitative approach. The qualitative research method is a research method using interviews as a source of data collection, observation and literature review as a source of theory collection. ${ }^{10}$ This research is descriptive qualitative which describes, summarizes various conditions, various situations or various social phenomena that exist in society to be the object of research. And type of this research are field research. The data collection used in the research was obtained in the following ways: interview, observation and documentation. In qualitative research, data is obtained from various sources, with various data collection techniques (triangulation) and is carried out continuously until the data is saturated. ${ }^{11}$ The data analysis used in this research is the Miles and Huberman model using the data reduction, presentation of data, and conclusion.

\section{Buying and Selling According to Fiqh Mu'amalah}

Etymologically, buying and selling means exchanging something absolutely. The words al-bay' and al-shira' in Arabic are used for the same meaning. Both are words that have two opposing meanings. In terms of Islamic law, buying and selling is the exchange of one asset for another based on mutual approval between the two parties, namely between the seller and the buyer. In addition, it can also be interpreted as the transfer of ownership of goods to other people with certain exchanges carried out in ways permitted by sharia. ${ }^{12}$

According to sharia, buying and selling is the exchange of certain assets with other assets, based on the pleasure of the seller and the buyer. Or in another sense, the exchange of property rights with other ownership is based on an agreement of material count and is based

\footnotetext{
${ }^{10}$ Sugiyono, Metode Penelitian Kuantitatif dan Kualitatif (Bandung: Alfabeta, 2009), 137.

${ }^{11}$ Sugiyono, Metode Penelitian Kuantitatif, Kualitaif dan R\&D (Bandung: Alfabeta, 2018), 246.

12 Sayyid Sabiq, Fiqh Sunnah, Vol. 3, trans. Asep Sobari (Jakarta: al-I'tishom, 2014), 263.
} 
on the pleasure of the transacting parties. As the hadith of the history of Ibn Majah and Ibn Hibban: ${ }^{13}$

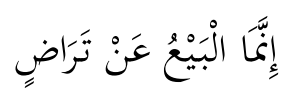

"In fact, buying and selling must be mutually consensual".

Because willingness is something that is not visible, the legal dependence on the law of sale and purchase can be seen from the visible way, which shows consensual, such as the existence of words of submission and acceptance.

Thus, the buying and selling process will involve two parties, namely the seller, who hands over the goods to the buyer, in exchange for money or property that he will receive, and the buyer who hands over the goods or money as delivery of the goods he receives.

\section{Legal Basis of Sale and Purchase}

Basically, the law of mu'amalah is permissible as agreed by the majority of fiqh scholars in their books which stipulate the rules of fiqhiyah which mentioned: ${ }^{14}$

$$
\text { الأصل في المعاملة الإباحة حتى يكون الدليل على التحريم }
$$

From this argument, the scholars take the rule that all forms of legal buying and selling are permitted except for buying and selling which is prohibited by Allah and His Messenger, namely buying and selling transactions that do not meet the legal requirements or there are prohibitions in the buying and selling element.

Buying and selling is an act or transaction that has been regulated in Islamic law, in the sense that there has been a clear law with regard to taklifi law. The law of buying and selling itself is basically permissible, as there are arguments from the al-Quran, hadith and ijma the scholars.

\section{Principles of Sale and Purchase}

The principles that must be considered in buying and selling are as follows:

1. The principle of freedom of transaction

This principle is based on the thinking of the jurists who argue that the origin of buying and selling is permissible, and is strengthened by the hadith:

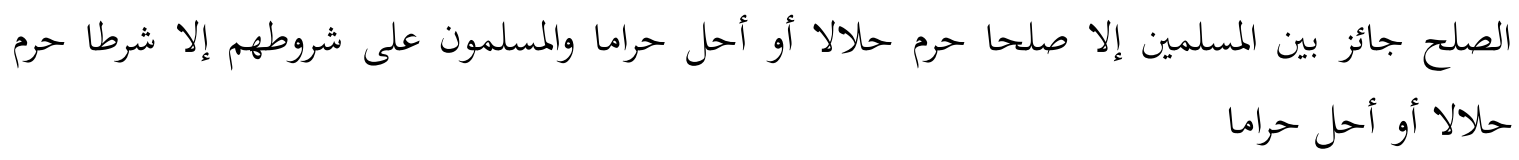

"Making peace with fellow Muslims is permissible except peace that justifies something that is haram or forbids something that is lawful. And the Muslims must fulfill the conditions they have agreed upon except the conditions that prohibit something that is lawful or justify something that is haram".

2. The principle of willingness

This principle is in accordance with the al-Quran: ${ }^{15}$

\footnotetext{
${ }^{13}$ Wahbah al-Zuhaili, al-Fiqh al-Islämiy wa Adillatuhū (Damaskus: Dar al-Fikri, 2004), 1237.

${ }^{14}$ Ali Djazuli, Kaidah-Kaidah Fikih (Jakarta: Prenada Media Grup, 2006), 130.

15 Syaifullahil Maslul, "Halal Food Products According to Islamic Business Ethics and Consumers Protection Law”, Jurnal al Iktisab, Volume 2, Number 2 (2018), 123.
} 


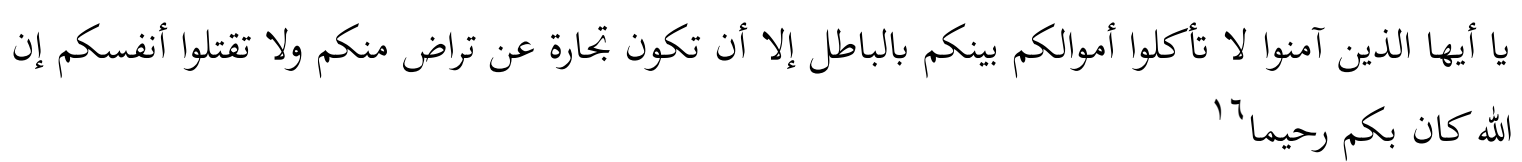

"O believers! Do not devour one another's wealth illegally, but rather trade by mutual consent. And do not kill each other or yourself. Surely Allah is ever Merciful to you".

3. The principle of balance in transactions

This principle is in accordance with the al-Quran:

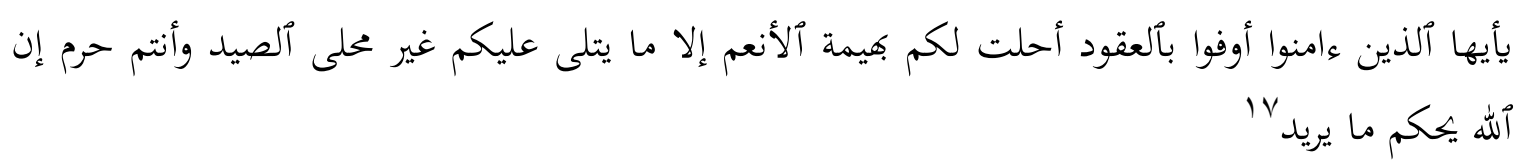

"O believers! Honour your obligations. All grazing livestock has been made lawful to you except what is hereby announced to you and hunting while on pilgrimage. Indeed, Allah commands what He wills".

4. The principle of permitting a contract (mubah)

This principle is in accordance with the al-Quran:

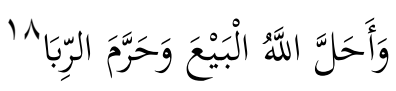

"But Allah has permitted trading and forbidden interest...".

5. Principles of Justice

This principle is in accordance with the al-Quran surah Ar Rahman verse 9:

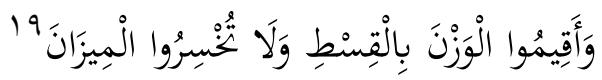

"Weigh with justice, and do not give short measure".

\section{Types and Forms of Sale and Purchase}

Buying and selling is a form of engagement in which it contains elements that are the principal of the sale and purchase. Those elements determine the form of the sale and purchase. In terms of sharia law, there are two types of buying and selling, namely buying and selling that are legal under sharia law, and those that are cancelled according to sharia law.

A sale and purchase can be said to be a valid sale and purchase if the sale and purchase is prescribed, fulfils the stipulated conditions and harmony, the goods being sold are not the ownership of others, and do not depend on khiyar rights anymore, then the sale and purchase can be said to be a valid sale and purchase. Sale and purchase can be referred to as a cancelled sale and purchase if one or all of the pillars are not fulfilled, or the sale and purchase is basically not required, such as buying and selling by crazy people, children, or the goods being sold are goods which are considered haram, such as blood, pork, carrion, and wine. Hanafiyah clerics distinguish fasid buying and selling from buying and selling that are cancelled. If the damage that occurs in the sale and purchase is related to the goods being traded, then the law is null and void, such as the sale and purchase of haram objects. And if

\footnotetext{
16 al-Quran, 4:29.

${ }^{17}$ Ibid, $5: 1$.

${ }^{18}$ Ibid, $2: 275$.

${ }^{19}$ Ibid, 55:9.
} 
the sale and purchase damage is related to the price of the goods and can be repaired, then the sale and purchase is called a fasid sale and purchase. ${ }^{20}$

\section{Buying and Selling Containing Gharār}

Gharär according to language means doubt, deception or action aimed at harming other parties. A contract contains an element of fraud, because there is no certainty whether or not there is a contract object, whether the contract object is large or small, or submitting the object of the contract. ${ }^{21}$ According to the term gharar, the sale and purchase of which the price, apparently, time, and place is uncertain, while in other terms it is buying and selling which contains roads (poverty roads) or mukhațara (speculation) or qumar (accusations).

In simple terms, gharär can be defined as a situation where one of the parties has information about various elements of the subject and object of the contract. Gharär is all trading that contains uncertainty or doubt about the existence of a commodity that is the object of the contract, unclear consequences, and the dangers that threaten profit and loss.

Gharar buying and selling is buying and selling that has no certainty about the goods. Buying and selling is risky and carries harm because it encourages someone to get what he wants while reversing it is detrimental and dangerous. Therefore, every sale and purchase that is still unclear or not in its power includes buying and selling of gharar. Gharä can be interpreted as uncertainty. Gharar or also known as taghrir is something where incomplete information occurs because of the uncertainty of the two transacting parties. Gharar occurs when we change something that is certain to become uncertain. ${ }^{22}$ Gharar can also occur in four ways, namely strength, quality, price and time of submission.

The greatness of the Islamic system in business emphasizes this very much, so that both parties are not wronged. Therefore, Islam requires several conditions for the validity of sale and purchase, without it, the sale and purchase and the contract are damaged, among these conditions are clear scales (clearly known and specific gravity weighed), goods and prices that are clear and understandable, and prices should not be majhul (unknown when buying), Has a tough tempo which is understandable, Mutual consent/rida of both parties regarding the business being carried out. ${ }^{23}$

According to Islamic principles, this practice of gharar breaks the contract. Islam safeguards human interests in this aspect. Imam al-Nawawi stated that the prohibition of gharär in Islamic business has a great role in ensuring justice. An example of buying and selling a gharär is buying and selling a calf that is still in its mother's stomach. Selling birds that fly in the air. It became gharär because it could not be ascertained. Is the fetus born, can the bird grasp it? So, if the price is paid, suddenly the goods are imperfect, then the buyer is dissatisfied, resulting in hostility and commotion.

Ibn Rushd al-Maliki emphasized, among the prohibited buying and selling contracts are various types of sale and purchase contracts that have the potential to cause harm to others, due to unclear status. And uncertainty in the sale and purchase agreement can be found at

\footnotetext{
${ }^{20}$ Nasrun Haroen, Fiqh Muammalah (Jakarta: Gaya Media Pertama, 2000), 121-125.

${ }^{21}$ M. Ali Hasan, Berbagai Macam Transaksi dalam Islam (Jakarta: PT Raja Grafindo Persada, 2003), 147-148.

${ }^{22}$ Mardani, Fiqih Ekonomi Syariah, 2.

${ }^{23}$ al-Imam al-Nawawi, al-Majmü', Sharh al-Muhazzab (Jakarta: Pustaka Azzam, 2003), 210.
} 
uncertainty in the determination of goods to be traded; uncertainty contract; price uncertainty; the uncertainty of the goods being traded; uncertainty in the level of prices or goods; uncertainty over the due date of payment or delivery of goods (if payment or delivery of goods is delayed); uncertainty whether or not the goods exist, or whether the seller is authorized to deliver the goods he is selling; uncertainty about whether the goods being traded are complete or not. ${ }^{24}$

Undoubtedly, the uncertainty over any of above can easily lead to disputes and enmity between fellow Muslim. Of course, Islamic law does not want this kind of schism and dispute. Therefore, Islamic law closes this door in order to maintain the integrity of unity and maintain a harmonious relationship between all components of the Muslim community.

The scholars have laid down clear rules in assessing whether the existing gharär is prohibited or condoned. al-Imam al-Mawardi provides guidance on a really good and clear method of identifying the gharar that is in a contract. He said that the nature of the gharar which is forbidden in the sale and purchase contract is a situation which has two possibilities, but the worst possibility is the most likely.

Based on al-Mawardi's explanation above, it can be concluded that the limit of gharar which is forbidden from being forgiven is if circumstances require us to put aside the existing gharär elements, because gharar is impossible to avoid except by bringing about very troublesome things, then such gharär is considered gharär which easy, so that it does not affect the law of buying and selling. On the other hand, if the gharar can be avoided without causing great trouble, then buying and selling containing gharar will be prohibited, null and void.

The scholars have also required several things that must be fulfilled so that a mu'amalah is considered forbidden because of gharär. First, the number of gharär is great and dominates the mu'amalah contract. Therefore, the scholars agree that a little gharar does not hinder the validity of the mu'amalah contract if it is impossible to be separated from the gharar as a whole. The scholars gave examples such as going into the toilet for a fee. It is understood that people who enter the toilet differ in how much water they use and how long they stay in the toilet. But because gharar is few, it does not dominate the mu'amalah contract and it is impossible for gharār to be avoided as a whole, the scholars allow it. ${ }^{25}$ Second, possibility to get away from gharar without difficulty. The scholars agree that the gharär which is impossible to spared from it except with great difficulty, then it can be forgiven. The scholars gave examples such as building foundations. People buying a house do not know what the foundation is like and it is very difficult to know, it is forgivable because it is very difficult to know that. Gharar like this is forgivable because it is hard to avoid. ${ }^{26}$ Third, there is no public interest that requires that the gharar be forgiven. Fourth, the gharār should be just a follower branch, not an origin or main one. And fifth, the gharär should be in ahkäm al-mu'awadat (laws of exchange/exchange) and what grows with it is like marriage.

\footnotetext{
${ }^{24}$ Ibn Rusyd, Bidāyah al-Mujtahid (Beirut: Dar al-Kutub al-Islāmi, 2007), 155.

${ }^{25}$ Abdul Ghafur Anshori, Perbankan Syari'ah di Indonesia (Yogyakarta: Universitas Gajah Mada, 2007 ), 87.

${ }^{26}$ Atang Hakim, Fiqh Perbankan Syari'ah (Bandung: Refika Aditama, 2011), 142.
} 


\section{Type of Gharair}

See form the incident, buying and selling of gharar can be viewed from three sides. First, buying and selling of goods that do not exist (ma'dum), such as buying and selling the habal al-habalah (fetuses of livestock). Second, buying and selling items that are not clear (majhul), both mutlaq, such as someone's statement "I sell goods at a price of one thousand rupiah", but the goods are not clearly known, or as someone says "I sold this car to you at a price ten million", but the types and characteristics are not clear. Or it could be because the size is not clear, like someone said "I sold the land to you for fifty million", but the size of the land is unknown. Third, buying and selling goods that cannot be handed over. Like buying and selling a runaway slave, or buying and selling a stolen car. ${ }^{27}$

This uncertainty also occurs in prices, goods and in the sale and purchase agreement. The uncertainty on prices can occur because of the amount, such as a handful of dinars. Meanwhile, there is no clarity on the goods, which is as explained above. As for the uncertainty in the contract, such as selling for 10 Dinar in cash and 20 Dinar in instalments, without specifying either of the two as payment. ${ }^{28}$

Shaykh as-Sa'di stated that the conclusion of buying and selling gharar goes back to buying and selling ma'dum (there is no form yet), such as habal al-habalah and al-sinin, or to buying and selling that cannot be handed over, like slaves who blurred and the like, or to obscurity, whether absolute on the goods, types or characteristics .

\section{Understanding Tadlis and Its Kinds}

The tadlis aspect in buying and selling transactions is actually classified as buying and selling which is gharar. Where the sale and purchase of gharar is a sale and purchase that contains elements of fraud and betrayal, either due to uncertainty in the object of sale and purchase or uncertainty in the way it is implemented. So that the law of buying and selling of this kind is prohibited (haram). Every transaction in Islam must be based on the principle of willingness between the two parties (are equally pleased). They must have the same information (complete information) so that neither party feels cheated because there are conditions that are unknown to one party (a situation where one party does not know information known to the other, which is called asymmetric information). Unknown to one party in fiqh language is called tadlis.

Tadlis can occur in four things in buying and selling. ${ }^{29}$ First, tadlis in quantity. One party (the seller), for example, reduces the estimate of goods that have been agreed between the seller and the buyer. The reduction in dosage, in this case, is known only to the seller. If the buyer is aware of this reduction, it is certain that the buyer will not be willing to buy and sell that has been done. Second, tadlis in quality. Quality includes hiding defects or poorquality goods that are not in accordance with what was agreed between the seller and the buyer. Third, tadlis in price. Tadlis (fraud) in this price includes selling goods at a price higher or lower than the market price because the buyer or seller does not find it, in fiqh it is called ghabn. Fourth, tadlis within the time of submission. The seller performs tadlis practice

\footnotetext{
${ }^{27}$ Abdul Ghafur Anshori, Perbankan Syari'ah, 89.

${ }^{28}$ Syekh Shalih Ibn al-Fauzani, al-Fiqh al-Bai' wa al-Shirä' (Riyadh: Dar al-Ashimah, 2011), 150.

${ }^{29}$ Adiwarman A. Karim, Bank Islam (Analisis Fiqih dan Keuangan) (Jakarta: Rajawali Pers, 2010), 31.
} 
at the time of delivery by masking his ability to deliver goods that are actually later than what he promised.

According to Wahbah al-Zuhaili, the contract containing tadlis is valid, while the fraud is haram. Wahbah al-Zuhaili here separates the validity of buying and selling which contains tadlis and the law from tadlis acts. Buying and selling that contains tadlis is legal, meaning that the sale and purchase contract is valid, while the act of tadlis is forbidden and a person who commits tadlis is committing one mistake from an act that is forbidden in Islam. Then Wahbah al-Zuhaili, divided tadlis into two kinds. First, hiding defects. This is called khiyar disgrace according to Hanafiyah scholars. According to the Hanafiyah scholars, khiyar disgrace is due to the lack of physical merchandise, even though the value does not decrease or may even increase. Second, the act of increasing the price of goods, even if they are not defective, such as collecting water from the seed grinder and then releasing it to show off for sale in order to increase the speed of rotation. Then the item is increased in price. ${ }^{30}$

\section{Fiqh Mu'amalah Review Regarding the Practice of Selling and Buying Products without a Price Tag}

A label is a part of a product that carries verbal information about the product or seller. The label becomes part of a product that conveys information about the product and the seller who is part of the packaging.

In the sale and purchase without a price tag by using the payment mechanism at the end, if the consumer does not ask for the price at the beginning of the transaction, business actors will be very vulnerable to playing the price in their sale and purchase. Price plays an important role in determining profits to business actors. The higher the price of goods, the higher the profits earned by the business actor. However, many do not understand that every time they increase the price of a good, the user is forced to bear the burden more. Related to this, Islam focuses more on justice and equality, as emphasized in the al-Quran:

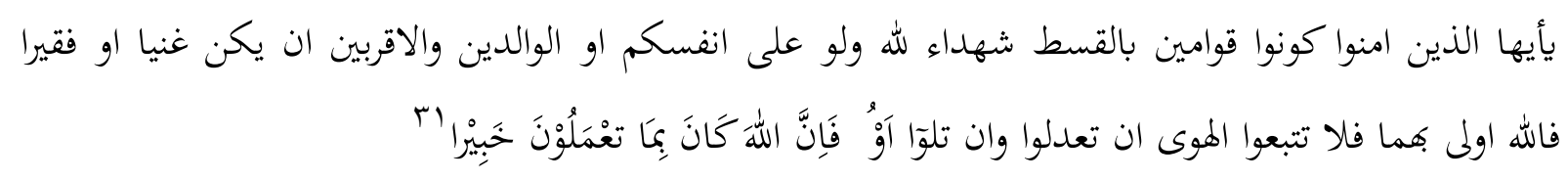

"O believers! Stand firm for justice as witnesses for Allah even if it is against yourselves, your parents, or close relatives. Be they rich or poor, Allah is the best to ensure their interest. So do not let your desires cause you to deviate 'from justice'. If you distort the testimony or refuse to give it, then 'know that' Allah is certainly AllAware of what you do."

In line with that, Islam also forbids injustice. In the al-Quran Allah says:

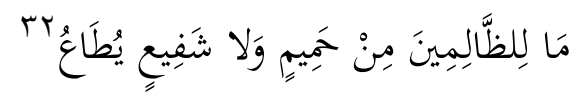

"The wrongdoers will have neither a close friend nor intercessor to be heard."

\footnotetext{
${ }^{30}$ Wahbah al-Zuhaili, al-Fiqh al-Islämiy, 1238.

${ }^{31}$ al-Quran, 4:135.

${ }^{32}$ Ibid, 40:18.
} 
In determining the price and policies of business actors regarding the ups and downs of the price of a product, there is actually no evidence from the al-Quran and hadis in detail that specifically addresses this issue. However, in general guidelines based on the principle of upholding justice and rejecting injustice as explained in the previous paragraphs, the price placed on an item that is to be issued should not oppress the user and do not neglect the seller's right to profit.

Buying and selling in general has pillars and conditions that must be met, so that the sale and purchase can be said to be legal or invalid. Buying and selling without a price tag in practice has generally fulfilled the pillars of buying and selling, where there are business actors and consumers as al-muta'aqidain, there is offer and acceptance, there are items that are purchased and there is an exchange value for goods substitutes. ${ }^{33}$ However, what becomes a problem is the contract or consent granted that occurs in the buying and selling mechanism without a price tag, in which there is no price information provided by the business actor at the beginning of the transaction.

The greatness of the Islamic system in business emphasizes this, so that both parties are not wronged. Therefore, Islam requires several conditions for the validity of sale and purchase, without which the sale and purchase and the contract are damaged, among these conditions are clear scales (clearly known and specific gravity weighed), goods and prices that are clear and understandable, and cannot be priced the majhul (unknown when buying), has an understandable tough tempo, and mutual consent/rida of both parties regarding the business being carried out. ${ }^{34}$

Because there is no information or transparency on the price of an item, consumers often feel that there is a price difference between the goods they buy and the market price of the goods. However, because consumers really need these goods, they are forced to buy these goods.

From previous problems, researcher analysed the problem that occurred with following description:

Table 1.1. Analysis Result

\begin{tabular}{|l|l|l|}
\hline \multicolumn{1}{|c|}{ Problem } & Analysis results & \multicolumn{1}{c|}{ Reason } \\
\hline $\begin{array}{l}\text { The management of the } \\
\text { Student Cooperative has } \\
\text { made several mistakes in } \\
\text { giving prices, because } \\
\text { there is no price tag, so } \\
\text { they give estimates }\end{array}$ & $\begin{array}{l}\text { If the management of the Student Cooperative is } \\
\text { wrong in giving the price, the selling price of the } \\
\text { item will be unclear, because there will be a } \\
\text { difference between the original price of the item } \\
\text { and the price given by the student cooperative } \\
\text { management. However, the principal price for } \\
\text { transactions in Student Cooperatives has been } \\
\text { clearly determined in nominal terms, so that its } \\
\text { uncertainly nature does not lie at the core of the } \\
\text { transaction. and also the error factor in giving } \\
\text { the price is an accident, and does not cause } \\
\text { hostility, so that the gharar contained therein is }\end{array}$ \\
\hline
\end{tabular}

${ }^{33}$ Mardani, Fiqih Ekonomi Syariah, 2.

${ }^{34}$ al-Imam al-Nawawi, al-Majmü', Sharh al-Muhazzab, 211. 


\begin{tabular}{|l|l|l|}
\hline $\begin{array}{l}\text { Some consumers are } \\
\text { reluctant to ask the } \\
\text { student cooperative } \\
\text { cashier about the price of } \\
\text { the goods to be } \\
\text { purchased, but consumers } \\
\text { really need the goods so } \\
\text { they seem to be forced to } \\
\text { buy these items, and it } \\
\text { turns out that the price is } \\
\text { different from what he } \\
\text { usually knows. }\end{array}$ & $\begin{array}{l}\text { considered light gharar } \\
\text { Shis transaction does not contain an element of } \\
\text { commitment, because the management of the } \\
\text { student cooperative has never forced consumers } \\
\text { to buy the goods being sold. In fact, many } \\
\text { consumers are happy to buy goods at the } \\
\text { Student Cooperative, even though the price is } \\
\text { more expensive, because they believe that when } \\
\text { cheated when they shop at } \\
\text { Student Cooperatives, } \\
\text { because the goods they } \\
\text { buy are more expensive } \\
\text { than usual. }\end{array}$ & $\begin{array}{l}\text { Not including tadlis be doing good. In accordance with the } \\
\text { motto in Student Cooperatives, "you shop, you } \\
\text { do charity". }\end{array}$ \\
\hline $\begin{array}{l}\text { The higher price was caused by the increase in } \\
\text { the cost of goods purchased, while the error in } \\
\text { the pure price was accidentally caused by the } \\
\text { management of the Student Cooperative because } \\
\text { they forgot the price of the item, so in this chase } \\
\text { two parts do not know each other about the price } \\
\text { and this is included in the gharar and not tadlis. } \\
\text { And there was no intention of cheating the } \\
\text { buyer, because the Student Cooperative } \\
\text { management held the principle of "A neat } \\
\text { administration is absolutely obligatory to } \\
\text { maintain trust". And also the principle "Allah } \\
\text { knows best". }\end{array}$ \\
\hline
\end{tabular}

From the result of the analysis above, it can be concluded that the trade without price tags occur in Student Cooperation store there's still a light gharar, that is the uncertainly in the price given at the time of transaction. However, the uncertainly in the pricing of this transaction only at the branch issue, not at the core of transaction. And the amount of uncertainly is only small and does not cause hostility, so the trade or buying and selling that occurs in the Student Cooperative Store is valid.

\section{Conclusion}

Based on the explanation above about the practice of buying and selling goods without price tags at the Student Cooperative Stores of Modern Islamic Boarding School Darussalam Gontor, Campus 5 Darul Qiyam, the researcher concluded that in the practice of buying and selling in Student Cooperatives, consumers take the goods they want to buy from the merchandise shelf and hand them over to the cashier, but because there is no price tag on the merchandise, many consumers do not know the price of the goods they are going to buy, so that it can result in price uncertainty, price differences and even fraud. As a result, consumers will feel disadvantaged because their rights are not fulfilled. Such as the right to get information and the right to price transparency. 
In fiqh mu'amalah, a contract on the practice of buying and selling goods without a price tag at the Student Cooperative of Modern Islamic Boarding School Darussalam Gontor, Campus 5, Darul Qiyam, Magelang, in general, it has fulfilled the pillars of buying and selling. but there's still a light gharar, that is the uncertainly in the price given at the time of transaction. However, the uncertainly in the pricing of this transaction only at the branch issue, not at the core of transaction. And the amount of uncertainly is only small and does not cause hostility, so the trade or buying and selling that occurs in the Student Cooperative Store is valid.

\section{References}

al-Nawawi. Al-Majmü' Sharh al-Muhazzab, Vol. 9, Trans. Muhammad Najib Al-Muthi'i. Jakarta: Pustaka Azzam, 2003.

al-Qardlawi, Yusuf. Halal Haram dalam Islam. Solo: Era Intermedia, 2000.

al-Zuhaili, Wahbah. al-Fiqh al-Islamiy wa adillatuhu. Damaskus: Dar al-Fikri, 2004.

Anshori, Abdul Ghafur. Perbankan Syari'ah di Indonesia. Yogyakarta: Universitas Gadjah Mada, 2007.

Djazuli, Ali. Kaidah-Kaidah Fikih. Jakarta: Prenada Media Grup, 2006.

Djuwaini, Dimyaudin. Pengantar Fiqh Muamalah. Yogyakarta: Pustaka Pelajar, 2008.

Hakim, Atang. Fiqh Perbankan Syari'ah. Bandung: Refika Aditama, 2011.

Haroen, Nasrun. Fiqh Muammalah. Jakarta: Gaya Media Pertama, 2000.

Hasan, M. Ali. Berbagai Macam Transaksi dalam Islam. Jakarta: PT Raja Grafindo Persada, 2003.

Ibn al-Fauzani, Syekh Shalih. al-Fiqh al-Bai' wa al-Shirä'. Riyadh: Darul Ashimah, 2011.

Ibn Rusyd. Bidāyah al-Mujtahid. Beirut: Dar al-Kutub al-Islami, 2007.

Karim, Adiwarman A. Bank Islam (Analisis Fiqih dan Keuangan). Jakarta: Rajawali Pers, 2010.

Mardani. Fiqih Ekonomi Syariah: Fiqih Muamalah. Jakarta: Kencana, 2012.

Maslulu, Syaifullahil. "Halal Food Products Labeling According to Islamic Business Ethics and Consumers Protection Law". Jurnal Al Iktisab, Volume 2, Number 2 (2018).

Mulyo, Hadi dan Shobahussurur. Falsafah dan Hikmah Hukum Islam. Semarang: CV. Adhi Grafika, 1992.

Muthiah, Aulia. "Perlindungan Konsumen terhadap Produk Cacat dalam Prespektif Fiqih Jual Beli”. Syariah: Jurnal Hukum dan Pemikiran, Volume 18, Number 2 (Desember 2018).

Parmujianto. "Analisis Fikih Mu'amalah Kontemporer terhadap Jual Beli Online dengan Sistem Transaksi Dropship (Kajian Hukum Islam)". Al Qodiri: Jurnal Pendidikan, Sosial dan Keagamaan, Volume 16, Number 1 (April 2019).

Pusat Pengkajian Hukum Islam dan Masyarakat Madani. Kompilasi Hukum Ekonomi Syariah. Jakarta: Kencana, 2009.

Rasyid, Sulaiman. Fiqh Islam. Bandung: Sinar Baru Algensindo, 2005.

Sabiq, Sayyid. Fiqih Sunnah, Vol. 12. Bandung: al-Ma'arif, 1980.

. Fiqh Sunnah, Vol. 3, trans. Asep Sobari. Jakarta: al-I'tishom, 2014.

Sugiyono. Metode Penelitian Kuantitatif dan Kualitatif. Bandung: Alfabeta, 2009.

. Metode Penelitian Kuantitatif, Kualitatif dan R\&D. Bandung: Alfabeta, 2018. 
Utami, Iyut Rizki. "Halal Food Product Labeling According to Islamic Business Ethics and Consumers Protection Law". Jurnal Al Iktisab, Volume 2, Number 2 (2018). 